\title{
Measuring instruments in cardiology adapted into Portuguese language of Brazil: a systematic review
}

\author{
INSTRUMENTOS DE MEDIDA EM CARDIOLOGIA ADAPTADOS PARA A LÍNGUA \\ PORTUGUESA DO BRASIL: UMA REVISÃO SISTEMÁTICA
}

\author{
INSTRUMENTOS DE MEDIDA EN CARDIOLOGÍA ADAPTADOS A LA LENGUA \\ PORTUGUESA DE BRASIL: UNA REVISIÓN SISTEMÁTICA
}

\section{Marilia Estevam Cornélio', Neusa Maria Costa Alexandre², Thaís Moreira São-João ${ }^{3}$}

\begin{abstract}
This was a systematic review aimed at identifying and characterizing measuring instruments, developed in the context of cardiology, which were adapted into Portuguese language of Brazil. Systematic searches were performed in six databases. Information extracted included cultural adaptation process and measurement properties. To assess the methodological quality of studies, criteria based on international guidelines for cultural adaptation of instruments were used. Among the 114 articles found, 14 were eligible for review. Of these, most evaluated quality of life (35.7\%) and health knowledge/learning (28.6\%). Most studies followed all stages of the adaptation process recommended in the literature. With respect to measurement properties, internal consistency, verified by Cronbach's alpha, was the property reported in the majority of the studies, as well as construct and criterion validity. This study is expected to provide to the scientific community a critical evaluation of adapted questionnaires available in the context of cardiology.
\end{abstract}

\section{DESCRIPTORS}

Questionnaires

Translating

Validation studies

Cardiology

Review

\section{RESUMO}

Revisão sistemática com o objetivo de identificar e caracterizar instrumentos de medida desenvolvidos no contexto da cardiologia que foram adaptados para a língua portuguesa do Brasil. Buscas sistematizadas foram realizadas em seis bases de dados. Extraíram-se informações referentes ao processo de adaptação cultural e as propriedades de medida. Para avaliação da qualidade metodológica dos estudos, foram utilizados critérios com base em diretrizes internacionais para adaptação cultural de instrumentos. Dentre os 114 artigos levantados, 14 foram considerados elegíveis para a revisão. Desses, a maioria avaliava qualidade de vida $(35,7 \%)$ e conhecimento/ aprendizagem em saúde $(28,6 \%)$. A maioria dos estudos contemplou todas as etapas do processo de adaptação recomendadas pela literatura. Com relação às propriedades de medida, a consistência interna, verificada por meio do alfa de Cronbach, foi a propriedade relatada na maioria dos estudos, bem como as validades de constructo e critério. Com este estudo, espera-se disponibilizar para a comunidade científica uma avaliação criteriosa dos questionários adaptados disponíveis no contexto da cardiologia.

\section{DESCRITORES \\ Questionários \\ Tradução \\ Estudos de validação \\ Cardiologia \\ Revisão}

\begin{abstract}
RESUMEN
Esta revisión sistemática tuvo como objetivo: identificar y caracterizar los instrumentos de medición desarrollados en el contexto de la cardiología que fueron adaptados a la lengua portuguesa de Brasil. Se llevaron a cabo búsquedas sistemáticas en seis bases de datos. Se extrajeron los datos sobre el proceso de adaptación cultural y las propiedades de medición. Para evaluar la calidad metodológica de los estudios, fueron utilizados criterios basados en las directrices internacionales para la adaptación cultural de instrumentos. Entre los 114 artículos encontrados, 14 fueron elegibles para su revisión. De los 14, la mayoría evaluaba la calidad de vida $(35,7 \%)$ y los procesos de conocimiento / aprendizaje en salud $(28,6 \%)$. La mayoría de los estudios incluyeron todas las etapas del proceso de adaptación recomendadas por la literatura. En relación a la medición de las propiedades, la consistencia interna, verificada por el alfa de Cronbach, fue la propiedad reportada en la mayoría de los estudios, así como la validez de constructo y la validez de criterio. Con este estudio, se espera brindar a la comunidad científica una cuidadosa evaluación de los cuestionarios adaptados disponibles en el contexto de la cardiología.
\end{abstract}

\section{DESCRIPTORES \\ Cuestionarios \\ Traducción \\ Estudios de validación \\ Cardiología \\ Revisión} ${ }^{1}$ Post-doctoral student, Faculty of Nursing, Campinas University, Campinas, SP, Brazil. mariliacornelio@gmail.com ${ }^{2}$ Associate Professor, Faculty of Nursing,
Campinas University, Campinas, SP, Brazil. ${ }^{3}$ Post-doctoral student, Faculty of Nursing, Campinas University, Campinas, SP, Brazil.

$\begin{aligned} \text { Rev Esc Enferm USP } & \text { Received: 09/09/2013 } \\ \text { 2014; } 48(2): 362-70 & \text { Approved: } 01 / 22 / 2014\end{aligned}$




\section{INTRODUCTION}

The literature reveals that cardiovascular diseases (CVD) are the leading cause of death and disability in the world $^{(1-2)}$. In Brazil, diseases of the circulatory system accounted for approximately $31 \%$ of all deaths in $2009^{(3)}$.

It is estimated that over $80 \%$ of CVD deaths are associated with known risk factors that can be prevented, such as smoking, physical inactivity and poor nutrition $^{(1)}$. However, prevention and treatment of these disorders often involve a complex scheme of lifestyle modification and the use of a wide range of medications, requiring a large investment of time for health professionals to promote awareness and patient adherence to recommendations, as well as the adoption of healthy behaviors.

In the context of CVD, the use of measuring instruments is an important resource in the development of exploratory research, whether diagnostic or experimental, for understanding the needs of individuals with these conditions and knowledge of health factors about which they wish to speak, as well as experimental designs that may be used as primary and secondary end-points ${ }^{(4)}$.

The use of measuring instruments allows one to obtain standardized data and compare results between different populations of the world ${ }^{(5)}$, and it is an economical and effective way to acquire reliable and valid outcome measures $^{(6)}$. It also allows one to transform subjective measures of objective data that can be quantified and analyzed in addition to investigating the impact of health interventions, enabling comparisons with less expenditure of time and financial resources ${ }^{(6)}$.

In exploratory research, a key step is the researcher's decision to use a previously developed instrument or to construct a specific tool to the completion of his study. Due to the complexity of the process of creating a new instrument and the existence of one that is already validated in another language to assess the same phenomenon, it is recommended to perform an adaptation of the tool to the desired culture ${ }^{(6)}$.

Cultural adaptation should result in a reliable and valid instrument, similar to the original, which can be used as a reference in research in many participating countries, thus becoming a tool for the comparison of results obtained in different cultures ${ }^{(5)}$. However, the cultural adaptation of an instrument for use in a new country, culture and/or language requires a methodology to achieve equivalence between the original source and the target language ${ }^{(7)}$.

This study aimed to identify questionnaires adapted into Portuguese language of Brazil used in the context of cardiology, to characterize the thematic areas of each, to assess the adaptation process that was adopted, and to describe the psychometric properties reported in the studies. This review is intended to provide insight to researchers and health professionals in identifying and choosing specific instruments for a particular study, in the context of cardiology.

\section{METHOD}

This was a literature research that can be defined as a systematic review. A systematic review is a rigorous methodology proposed to identify studies on a topic in question, through the application of systematic methods to search, and to evaluate the quality, validity and applicability of these studies in the context in which the changes will be implemented ${ }^{(8)}$ To meet the objectives of this study, we performed a systematic review based on the international protocol called PRISMA ${ }^{(9)}$, which included the following methodological steps: 1) search strategies, 2) inclusion and exclusion criteria, 3) data extraction and as sessment of methodological quality of eligible studies.

\section{Search strategies}

We conducted a systematic and sequential search in the following databases: Thomson Reuters Web of Knowledge, SCOPUS, Cumulative Index to Nursing and Allied Health Literature (CINAHL), Literature Latin American and Caribbean Health Sciences (LILACS), Medline and Scientific Electronic Library Online (SciELO). A combination of terms and/or keywords was used to ensure the maximum capture of articles (cultural OR valid OR trad OR psychomet OR adapt) AND (questionnaire OR instrument OR scale) AND (card OR coronar OR heart OR hypertension) AND (Portuguese OR Brazil).

After searching databases, two authors conducted a critical reading of the titles and review of the abstracts to identify relevant articles according to the inclusion criteria. Articles were classified as included, excluded or doubt. Those that generated doubts were evaluated by three researchers (two of them participated in the primary reading) to determine, by consensus, a final decision.

\section{Criteria for inclusion and exclusion}

Articles in Portuguese and/or English, published between 1990 e 2013, were included to describe the process of cultural adaptation to Portuguese language of Brazil, with abstracts and full texts available in selected databases. We excluded those that did not follow the methodological process of cultural adaptation of instruments recommended by international guidelines ${ }^{(7)}$ and those that were not placed in the context of cardiology.

\section{Data extraction and assessment of methodological quality of eligible studies}

The data were obtained using a standard form developed for the purpose of ensuring the homogeneous 
extraction of information from the items. Firstly, characterization data were extracted from the instruments, and after, data related to translation and cultural adaptation were obtained in order to evaluate the quality of these processes, and also data regarding the psychometric properties of each study.

To evaluate the translation and cultural adaptation process, the studies were classified according to the criteria described in the Guidelines for the Process of Cross-Cultural Adaptation of Self-Report Measures ${ }^{(7)}$, which include the following steps: translation, synthesis of translations, back translation, review by the expert committee, and pretesting. To do so, each step was classified as follows: positive $(+)$, doubtful(?) and negative $(-)^{(10)}$ (Chart 1). The doubt classification was attributed to the step which was performed in a questionable form, or, that was not performed according to the recommendations of the Guidelines ${ }^{(7)}$, such as, for example, in the translation stage, the translators did not have as the native language that of the original instrument.

With regard to the psychometric properties of the instruments, it was decided to make a description of the tests performed and reported in the studies, since there is not yet a global consensus on the criteria for evaluation of the psychometric properties of instruments developed, adapted and validated, although there are initiatives for this purpose, such as the Consensus-based Standards for the selection of Health Measurement Instruments (COSMIN) $)^{(11)}$.

Chart 1 - Guidelines for procedures of cultural adaptation of questionnaires ${ }^{(7,10)}$

\begin{tabular}{|c|c|c|}
\hline Step & Description & Classification scheme \\
\hline Translation & $\begin{array}{l}\text { Two or more translators must translate the questionnaire } \\
\text { independently. The native language of the translator should be the } \\
\text { target language of the translation. }\end{array}$ & $\begin{array}{l}\text { + Translation by at least two } \\
\text { independent translators; } \\
\text { ? Questionable procedure for } \\
\text { translation; } \\
\text { - Translation done by only one } \\
\text { translator; } \\
0 \text { No information about the } \\
\text { translation process. }\end{array}$ \\
\hline Synthesis & $\begin{array}{l}\text { Translators must synthesize translations and produce a consensus } \\
\text { version. }\end{array}$ & $\begin{array}{l}\text { + Synthesis performed; } \\
\text { ? Questionable design; } \\
0 \text { No information about the } \\
\text { synthesis, or translation was done by } \\
\text { only one translator. }\end{array}$ \\
\hline Back translation & $\begin{array}{l}\text { Translators who have no knowledge of the original questionnaire } \\
\text { should translate the consensus version of the translation back to the } \\
\text { original language of the questionnaire. }\end{array}$ & $\begin{array}{l}\text { + Back translation conducted by at } \\
\text { least two independent translators; } \\
\text { ? Procedure of questionable back- } \\
\text { translation; } \\
\text { - Back translation done by a } \\
\text { translator; } \\
0 \text { No information about the process } \\
\text { of back-translation. }\end{array}$ \\
\hline Analysis of the committee & $\begin{array}{l}\text { The expert committee examine all versions of the questionnaire and } \\
\text { develop the pre-final version of the questionnaire. }\end{array}$ & $\begin{array}{l}+ \text { The existence of a committee of } \\
\text { experts was clearly reported; } \\
\text { ? Questionable design; } \\
0 \text { No information about the expert } \\
\text { committee. }\end{array}$ \\
\hline $\begin{array}{l}\text { Pretesting of pre-final } \\
\text { version }\end{array}$ & $\begin{array}{l}\text { The pre-final version of the questionnaire should be tested on members } \\
\text { of the target population. }\end{array}$ & $\begin{array}{l}\text { + Pre-test was performed; } \\
\text { ? Questionable design; } \\
0 \text { No information on the pre-test }\end{array}$ \\
\hline
\end{tabular}

+ = Positive rating, - = negative rating, 0 = no information available; ? = Unclear.

The relevant psychometric properties are described below for the process of cultural adaptation as reported in the selected studies. The definitions of each property, in accordance with the international literature, were used ${ }^{(12)}$ :

Internal consistency: measure of homogeneity of a (sub)scale of a questionnaire that indicates the degree to which items in a (sub)scale are related to each other, measuring the same concept (construct), assessed by means of the Cronbach's alpha coefficient;
Stability: known also by reproducibility, refers to the degree to which repeated measurements in stable individuals provide similar answers (test-retest) and is assessed by the Intraclass Correlation Coefficient (ICC) or via the Kappa coefficient (interobserver);

Construct validity: examines the extent to which each score of a specific questionnaire is related to other measures, so that it is consistent with the hypotheses related to the concepts being measured. It can be 
performed by exploratory or confirmatory factor analysis, comparison tests between known groups, or correlation tests with scores of questionnaires to assess similar constructs as the target instrument;

Criterion validity: refers to the extent to which the scores of an instrument relates to a gold standard, commonly assessed by the correlation between the scores of the instrument and the values obtained with the gold standard tests.

\section{RESULTS}

A search in the databases identified 114 articles. After reading the titles, abstracts and considering the inclusion and exclusion criteria, 14 articles were included in the systematic review on cultural adaptation to Portuguese language of Brazil of instruments developed in the context of cardiology (Figure 1). The exclusion of studies occurred for the following reasons: duplication of articles in databases $(n=23)$, instruments outside the context of cardiology $(n=15)$, items that were not related to the adaptation of instruments $(n=61)$, and one article on adaptation to Portuguese language of Portugal.

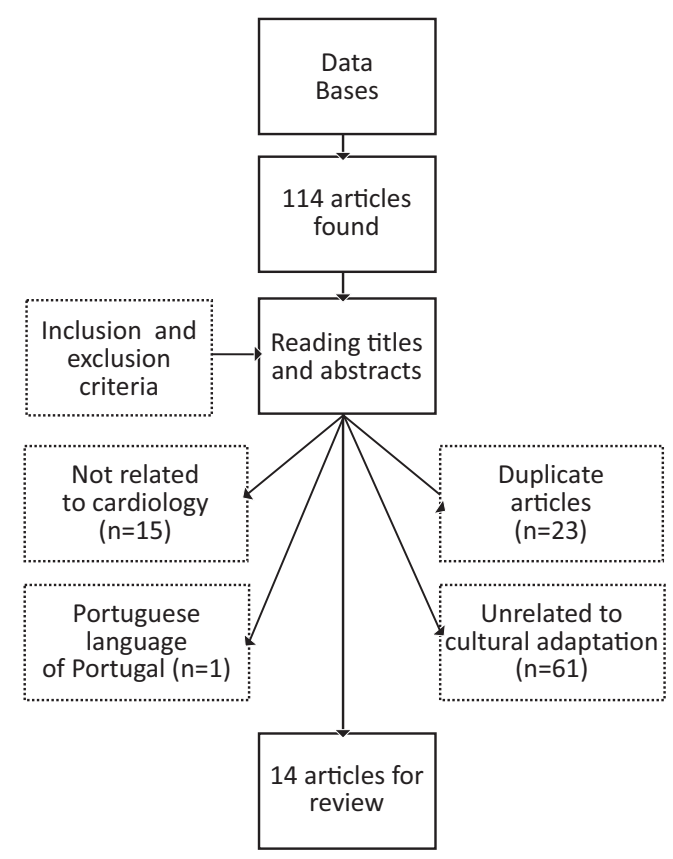

Figure 1 - Flowchart of articles found and evaluated after applying the criteria for inclusion and exclusion

Of the 14 instruments identified, all were recent in terms of the year of publication (beginning in the year 2006), and most were originally developed in the decades of the 1990s and 2000s. The country of origin for eight of them was the United States of America.
Regarding the purpose, five (35.7\%) assessed quality of life, four (28.6\%) assessed health knowledge/learning processes, two (14.3\%) assessed determinants of health-related behaviors; two $(14,3 \%)$ symptom/functional capacity; and one (7.1\%) estimated the frequency of self-care (Chart 2).

The evaluation of the cultural adaptation process is described in Chart 3. The results indicate that most of the adaptation were performed according to the established criteria, having been classified as positive in at least three of the five steps recommended in the literature ${ }^{(7)}$. However, in the adaptation of the DASS ${ }^{(13)}$ instrument, the stage of review by the committee of experts was performed before performing the back-translations.

In the adaptation of the Bulpitt and Fletcher Quality of Life Instrument for Hypertensives ${ }^{(20)}$, the translation stage was conducted by two native speakers from the country of origin of the instrument, but there was no information about the synthesis of the translations. In MINICHAL ${ }^{(23)}$, the back-translation was performed only by a translator. In adapting the $\mathrm{CBRS}^{(26)}$ instrument, the back-translation was also performed only by a translator and there was no information on the pre-test.

With regard to the psychometric properties of the adapted instruments, Chart 4 shows that at least one property was tested on each instrument. The internal consistency, stability, construct validity and criterion validity were the properties assessed in most studies.

The internal consistency, evaluated by means of Cronbach's alpha, was observed in all instruments except for the VSAQ ${ }^{(14)}, \mathrm{MDI}^{(15)}$, and Disease Knowledge and Self-Care Questionnaire for Heart Failure Patients ${ }^{(21)}$, in which such properties were not applicable, and the Bulpitt and Fletcher Quality of Life Instrument for Hypertensives ${ }^{(20)}$, in which there was no information.

Stability, known as reproducibility in some studies, was evaluated in five instruments by means of Kappa index, with values above $0.60^{(14-15,18-19,21)}$, and by means of Intraclass Correlation Coefficient (ICC) on three instruments, also with values above $0.60^{(17,22,26)}$. There were no reports of stability analysis in three studies ${ }^{(13,20,23)}$.

The validation process was described in only six articles $^{(13,20,23-26)}$. Construct validity was assessed in the DASS $^{(13)}$, Bulpitt and Fletcher Quality of Life Instrument for Hypertensives(20), MINICHAL ${ }^{(23)}, \mathrm{MICRO}^{(20)}{ }^{(24)}$, AQUAREL ${ }^{(25)}$, and $\mathrm{CRBS}^{(26)}$ instruments, and exploratory factor analysis was performed in four of these $\mathrm{e}^{(13,23-24,26)}$. Criterion validity, following the description and the name contained in the selected articles, was assessed in four instruments: Bulpitt and Fletcher Quality of Life Instrument for Hypertensives ${ }^{(20)}, \mathrm{MINICHAL}^{(23)}$, AQUAREL ${ }^{(25)}$ and $\mathrm{CRBS}^{(26)}$. 
Chart 2 - Description of the questionnaires developed in the context of cardiology and adapted into Portuguese language of Brazil

\begin{tabular}{|c|c|c|c|c|}
\hline Instrument & $\begin{array}{c}\text { Authors and year of } \\
\text { adaptation }\end{array}$ & $\begin{array}{l}\text { Authors, year and the } \\
\text { place of origin of the } \\
\text { instrument }\end{array}$ & $\begin{array}{l}\text { Purpose of the } \\
\text { instrument }\end{array}$ & Subject \\
\hline $\begin{array}{l}\text { Veterans } \\
\text { Specific Activity } \\
\text { Questionnaire } \\
\text { (VSAQ) }^{(14)} \\
\end{array}$ & Domingues et al., 2011 & $\begin{array}{l}\text { Myers et al., } 1994 \\
\text { USA }\end{array}$ & $\begin{array}{l}\text { Determine the threshold } \\
\text { level of physical } \\
\text { activity by triggering } \\
\text { cardiovascular symptoms }\end{array}$ & Cardiac \\
\hline $\begin{array}{l}\text { Modified Dyspnea } \\
\text { Index (MDI) }\end{array}$ & Miura et al., 2012 & $\begin{array}{l}\text { Stoller et al., } 1986 \\
\text { USA }\end{array}$ & $\begin{array}{l}\text { Assess the impact or } \\
\text { limitation imposed by } \\
\text { dyspnea }\end{array}$ & $\begin{array}{l}\text { Cardiac patients } \\
\text { complaining of } \\
\text { dyspnoea dyspnea }\end{array}$ \\
\hline $\begin{array}{l}\text { Cardiac Patient } \\
\text { Learning Needs } \\
\text { Inventory } \\
(\text { CPLNI) }\end{array}$ & Galdeano et al., 2012 & $\begin{array}{l}\text { Gerard e Peterson, } 1984 \\
\text { USA }\end{array}$ & $\begin{array}{l}\text { Identify the learning } \\
\text { needs of cardiac patients } \\
\text { in relation to disease } \\
\text { cardiac patients in } \\
\text { relation to disease }\end{array}$ & $\begin{array}{l}\text { Subjects admitted to } \\
\text { the cardiology ward or } \\
\text { coronary care unit } \\
\text { the cardiology or } \\
\text { coronary care unit }\end{array}$ \\
\hline $\begin{array}{l}\text { European Heart } \\
\text { Failure Self-care } \\
\text { Behavior Scale } \\
(\text { EHFScBS })^{(17)}\end{array}$ & Feijó et al., 2012 & $\begin{array}{l}\text { Jaarsma et al., } 2003 \\
\text { Europe }\end{array}$ & $\begin{array}{l}\text { Assess self-care } \\
\text { in patients with heart } \\
\text { failure }\end{array}$ & $\begin{array}{l}\text { Patients with heart } \\
\text { failure of any etiology }\end{array}$ \\
\hline $\begin{array}{l}\text { Nurses' Knowledge } \\
\text { of heart Failure } \\
\text { Education Principles } \\
(\text { NKHF) } \\
\text { (18) }\end{array}$ & Klein et al., 2012 & $\begin{array}{l}\text { Albert et al., } 2002 \\
\text { USA }\end{array}$ & $\begin{array}{l}\text { Assess the knowledge of } \\
\text { nurses about heart failure } \\
\text { nurses about heart failure }\end{array}$ & Nurses \\
\hline $\begin{array}{l}\text { Dietary Sodium } \\
\text { Restriction } \\
\text { Questionnaire } \\
\text { (DSRQ) }^{(19)}\end{array}$ & d'Almeida et al., 2012 & $\begin{array}{l}\text { Bentley et al., } 2009 \\
\text { USA }\end{array}$ & $\begin{array}{l}\text { Identify factors affecting } \\
\text { adherence to the diet with } \\
\text { low sodium adherence to } \\
\text { the diet with low sodium }\end{array}$ & $\begin{array}{l}\text { Patients with } \\
\text { heart failure }\end{array}$ \\
\hline $\begin{array}{l}\text { Duke } \\
\text { Anticoagulation } \\
\text { Satisfaction Scale } \\
\text { (DASS) }^{(13)}\end{array}$ & Pelegrino et al., 2011 & $\begin{array}{l}\text { Samsa et al., } 2004 \\
\text { USA }\end{array}$ & $\begin{array}{l}\text { Measuring quality of } \\
\text { life and satisfaction } \\
\text { of patients on oral } \\
\text { anticoagulants treatment }\end{array}$ & $\begin{array}{l}\text { Patients on oral } \\
\text { anticoagulants treatment }\end{array}$ \\
\hline $\begin{array}{l}\text { Evaluation } \\
\text { Instrument for } \\
\text { Quality of Life } \\
\text { for Hypertensives } \\
\text { of Bulpitt and } \\
\text { Fletcher }{ }^{(20)}\end{array}$ & Gusmão e Pierin, 2009 & $\begin{array}{l}\text { Bulpitt e Fletcher, } 1990 \\
\text { England }\end{array}$ & $\begin{array}{l}\text { Evaluate the impact of } \\
\text { hypertension on quality } \\
\text { of life }\end{array}$ & $\begin{array}{l}\text { Hypertensive and } \\
\text { normotensive } \\
\text { normotensive patients in } \\
\text { outpatient treatment }\end{array}$ \\
\hline $\begin{array}{l}\text { Disease Knowledge } \\
\text { and Self-Care } \\
\text { Questionnaire } \\
\text { for Heart Failure } \\
\text { Patients }\end{array}$ & Rabelo et al., 2011 & $\begin{array}{l}\text { Artinian et al., } 2002 \\
\text { USA }\end{array}$ & $\begin{array}{l}\text { Assessment of knowledge } \\
\text { of disease and self } \\
\text { disease and self-care } \\
\text { in patients with heart } \\
\text { failure }\end{array}$ & $\begin{array}{l}\text { Patients with } \\
\text { heart failure }\end{array}$ \\
\hline $\begin{array}{l}\text { Minnesota Living } \\
\text { with Heart Failure } \\
\text { Questionnaire } \\
\text { (MLHFQ) }^{(22)}\end{array}$ & Carvalho et al., 2009 & $\begin{array}{l}\text { Rector et al., } 1997 \\
\text { USA }\end{array}$ & $\begin{array}{l}\text { Measuring quality of life } \\
\text { in subjects with heart } \\
\text { failure }\end{array}$ & $\begin{array}{l}\text { Patients with } \\
\text { heart failure }\end{array}$ \\
\hline $\begin{array}{l}\text { Mini-Cuestionario } \\
\text { de Calidad Vida em } \\
\text { hipertensión Arterial } \\
\text { (MINICHAL) }^{(23)}\end{array}$ & Schulz et al., 2008 & $\begin{array}{l}\text { Badia et al., } 2002 \\
\text { Spain }\end{array}$ & $\begin{array}{l}\text { Assessing quality of } \\
\text { life related to health in } \\
\text { hypertensive patients }\end{array}$ & $\begin{array}{l}\text { Hypertensive and } \\
\text { normotensive subjects }\end{array}$ \\
\hline $\begin{array}{l}\text { Maugerl CaRdiac } \\
\text { preventiOn- } \\
\text { Questionnaire } \\
\text { (MICRO-Q) }^{(24)}\end{array}$ & Ghisi et al., 2010 & $\begin{array}{l}\text { Sommaruga et al., } 2003 \\
\text { Italy }\end{array}$ & $\begin{array}{l}\text { Assess the level of } \\
\text { knowledge regarding } \\
\text { secondary prevention in } \\
\text { patients with coronary } \\
\text { artery disease }\end{array}$ & $\begin{array}{l}\text { Patients with coronary } \\
\text { artery disease }\end{array}$ \\
\hline $\begin{array}{l}\text { Assessment of } \\
\text { QUAlity of life and } \\
\text { RELated events } \\
\text { (AQUAREL) }^{(25)}\end{array}$ & Oliveira et al., 2006 & $\begin{array}{l}\text { Stofmeel et al., } 2001 \\
\text { Netherland }\end{array}$ & $\begin{array}{l}\text { Assessing quality of } \\
\text { life in patients with } \\
\text { pacemakers }\end{array}$ & Patients with pacemaker \\
\hline $\begin{array}{l}\text { Cardiac } \\
\text { Rehabilitation } \\
\text { Barriers Scale } \\
(\text { CRBS })^{(26)}\end{array}$ & Ghisi et al., 2012 & $\begin{array}{l}\text { Shanmugasegaram et } \\
\text { al., 2011 } \\
\text { Canada }\end{array}$ & $\begin{array}{l}\text { Assess the perception } \\
\text { of the barriers to } \\
\text { participation and } \\
\text { adherence to cardiac } \\
\text { rehabilitation programs }\end{array}$ & $\begin{array}{l}\text { Subjects with any } \\
\text { disease or comorbidity } \\
\text { that requires treatment } \\
\text { by cardiac rehabilitation }\end{array}$ \\
\hline
\end{tabular}


Chart 3 - Analysis of adaptations of measuring instruments developed in the context of cardiology into Portuguese language of Brazil

\begin{tabular}{|c|c|c|c|c|c|}
\hline Instrument & Translation & Synthesis & $\begin{array}{c}\text { Back } \\
\text { translation }\end{array}$ & $\begin{array}{l}\text { Committee } \\
\text { of experts }\end{array}$ & Pre-test \\
\hline VSAQ & + & + & + & + & + \\
\hline MDI & + & + & + & + & + \\
\hline CPLNI & + & + & + & + & + \\
\hline Instrument & Translation & Synthesis & $\begin{array}{c}\text { Back } \\
\text { translation }\end{array}$ & $\begin{array}{l}\text { Committee } \\
\text { of experts }\end{array}$ & Pre-test \\
\hline EHFScBS & + & + & + & + & + \\
\hline NKHF & + & + & + & + & + \\
\hline DSRQ & + & + & + & + & + \\
\hline DASS & + & + & + & $?$ & + \\
\hline Instrumento de Bulpitt e Fletcher & $?$ & 0 & + & + & + \\
\hline $\begin{array}{l}\text { Disease Knowledge and Self-Care } \\
\text { Questionnaire for Heart Failure Patients }\end{array}$ & + & + & + & + & + \\
\hline MLHFQ & + & + & + & + & + \\
\hline MINICHAL & + & + & - & + & + \\
\hline MICRO-Q & + & + & + & + & + \\
\hline AQUAREL & + & + & + & + & + \\
\hline CRBS & + & + & - & + & 0 \\
\hline
\end{tabular}

$+=$ Positive rating, - = negative rating, $0=$ no information available; $?=$ Unclear

Chart 4 - Description of the psychometric properties of the versions of instruments developed in the context of cardiology in Portuguese language of Brazil

\begin{tabular}{|c|c|c|c|c|c|c|c|c|}
\hline \multirow[b]{2}{*}{ Instrument } & \multicolumn{2}{|c|}{ Internal consistency } & \multicolumn{2}{|c|}{ Stability } & \multicolumn{2}{|c|}{ Construct validity } & \multicolumn{2}{|c|}{ Criterion validity } \\
\hline & $\begin{array}{l}\text { Statistical } \\
\text { test }\end{array}$ & Result & $\begin{array}{l}\text { Statistical } \\
\text { test }\end{array}$ & Result & $\begin{array}{l}\text { Statistical } \\
\text { test }\end{array}$ & Result & Statistical test & Result \\
\hline VSAQ & N/A* & - & Kappa & $\begin{array}{c}0.86 \\
(p<0.01)\end{array}$ & \multicolumn{2}{|c|}{ Not reported } & \multicolumn{2}{|c|}{ Not reported } \\
\hline MDI & N/A & - & Kappa & $\begin{array}{c}0.96 \\
(p<0.001)\end{array}$ & \multicolumn{2}{|c|}{ Not reported } & \multicolumn{2}{|c|}{ Not reported } \\
\hline CPLNI & $\begin{array}{l}\text { Cronbach's } \\
\text { alpha }\end{array}$ & 0,96 & $\begin{array}{c}\text { Student } \\
\text { t-test }\end{array}$ & $\mathrm{p}>0.05$ & \multicolumn{2}{|c|}{ Not reported } & \multicolumn{2}{|c|}{ Not reported } \\
\hline EHFScBS & $\begin{array}{l}\text { Cronbach's } \\
\text { alpha }\end{array}$ & $0,61-0,70$ & $\mathrm{ICC} \dagger$ & 0.87 & \multicolumn{2}{|c|}{ Not reported } & \multicolumn{2}{|c|}{ Not reported } \\
\hline NKHF & $\begin{array}{l}\text { Cronbach's } \\
\text { alpha }\end{array}$ & 0,70 & Kappa & $\begin{array}{l}\geq 0.70 \\
\text { Q4, Q5 e } \\
\text { Q11 } \leq 0.4\end{array}$ & \multicolumn{2}{|c|}{ Not reported } & \multicolumn{2}{|c|}{ Not reported } \\
\hline DSRQ & $\begin{array}{l}\text { Cronbach's } \\
\text { alpha }\end{array}$ & 0,77 & Kappa & $\geq 0.62$ & \multicolumn{2}{|c|}{ Not reported } & \multicolumn{2}{|c|}{ Not reported } \\
\hline DASS & $\begin{array}{l}\text { Cronbach's } \\
\text { alpha }\end{array}$ & 0,79 & \multicolumn{2}{|c|}{ Not reported } & $\begin{array}{c}\text { Pearson } \\
\text { EFAt }\end{array}$ & $\begin{array}{c}\mathrm{r} \geq-0.22 \\
(\mathrm{p}<0.01) \\
>3 \\
\text { components } \\
\end{array}$ & Not $r$ & orted \\
\hline $\begin{array}{l}\text { Bulpitt } \\
\text { \&Fletcher } \\
\text { Instrument }\end{array}$ & \multicolumn{2}{|c|}{ Not reported } & \multicolumn{2}{|c|}{ Not reported } & Chi-square & $\mathrm{p}<0.05$ & Correlation & $\begin{array}{l}\text { Significantin } \\
\text { some areas }\end{array}$ \\
\hline $\begin{array}{l}\text { Disease } \\
\text { Knowledge } \\
\text { and Self-Care } \\
\text { Questionnaire } \\
\text { for Heart } \\
\text { Failure } \\
\text { Patients }\end{array}$ & \multicolumn{2}{|c|}{ N/A } & Kappa & $\begin{array}{c}>0.60 \\
\text { Q7: } 0.40\end{array}$ & \multicolumn{2}{|c|}{ Not reported } & \multicolumn{2}{|c|}{ Not reported } \\
\hline MLHFQ & $\begin{array}{c}\text { Cronbach's } \\
\text { alpha }\end{array}$ & 0.97 & ICC & $\begin{array}{c}0.97 \\
(\mathrm{p}<0.01)\end{array}$ & \multicolumn{2}{|c|}{ Not reported } & \multicolumn{2}{|c|}{ Not reported } \\
\hline
\end{tabular}


Continuation...

\begin{tabular}{|c|c|c|c|c|c|c|c|c|}
\hline \multirow{2}{*}{ Instrument } & \multicolumn{2}{|c|}{ Internal consistency } & \multicolumn{2}{|c|}{ Stability } & \multicolumn{2}{|c|}{ Construct validity } & \multicolumn{2}{|c|}{ Criterion validity } \\
\hline & $\begin{array}{c}\text { Statistical } \\
\text { test }\end{array}$ & Result & $\begin{array}{c}\text { Statistical } \\
\text { test }\end{array}$ & Result & $\begin{array}{c}\text { Statistical } \\
\text { test }\end{array}$ & Result & Statistical test & Result \\
\hline MINICHAL & $\begin{array}{c}\text { Cronbach's } \\
\text { alpha }\end{array}$ & $0.88-0.86$ & \multicolumn{2}{|c|}{ Not reported } & EFA & $\begin{array}{c}2 \\
\text { components }\end{array}$ & Student t-test & $\mathrm{p}<0.001$ \\
\hline MICRO-Q & $\begin{array}{c}\text { Cronbach's } \\
\text { alpha }\end{array}$ & 0.64 & $\begin{array}{c}\text { Spearman's } \\
\text { rho }\end{array}$ & $\begin{array}{c}\text { r: } \\
0.10-0.65\end{array}$ & EFA & $\begin{array}{c}6 \\
\text { components }\end{array}$ & \multicolumn{2}{|c|}{ Not reported } \\
\hline AQUAREL & $\begin{array}{c}\text { Cronbach's } \\
\text { alpha }\end{array}$ & $0.68-0.85$ & $\begin{array}{c}\text { Student } \\
\text { t-test, } \\
\text { Pearson's } \\
\text { correlation }\end{array}$ & $\begin{array}{c}p>0.5 \\
r: 0.81 \\
(p<0.01)\end{array}$ & $\begin{array}{c}\text { Correlação } \\
\text { de Pearson } \\
\text { teste de } \\
\text { Tukey }\end{array}$ & $\begin{array}{c}\mathrm{r}: 0.25- \\
0.68 \\
\mathrm{p}<0.01\end{array}$ & Correlation & $\mathrm{p}>0.54$ \\
\hline CRBS & $\begin{array}{c}\text { Cronbach's } \\
\text { alpha }\end{array}$ & 0.88 & $\mathrm{ICC}$ & 0.68 & EFA & $\begin{array}{c}5 \\
\text { components }\end{array}$ & Student t-test & $\mathrm{p}<0.001$ \\
\hline
\end{tabular}

*N/A: not applicable; † ICC: intraclass correlation coefficient; ‡ EFA: exploratory factor analysis.

\section{DISCUSSION}

This systematic review aimed at identifying questionnaires developed in the context of cardiology which were adapted into Portuguese language of Brazil and characterizing them in terms of their purpose, target population and cultural adaptation process, and describe their measurement properties.

In total, 14 articles developed in the cardiology context were selected in which the adaptation process was described. Of these, most were developed to assess quality of life related to adverse conditions, such as hypertension, heart failure, use of a pacemaker, and oral anticoagulants. Most studies included all stages of the adaptation process recommended by literature. The others followed at least three of the five recommended steps. With respect to measurement properties, internal consistency, verified by means of Cronbach's alpha, was reported in all but four articles - three of them did not apply and it was not reported in a single study. Stability was not reported in only three studies. The construct and criterion validity were verified and reported in most articles.

The fact that most of the instruments identified in this review is related to the assessment of quality of life in several cardiac diseases was not surprising, since cardiovascular conditions are, in their majority, chronic diseases that, in addition to having a high prevalence and incidence in the population, have an important impact on the physical, psychological and social aspects of the subject.

Data concerned to the evaluation of the adaptation process indicate that most of the studies used a consistent methodological basis, following the steps of translation, synthesis, back translation, review by the expert committee, and pretesting. The criteria used to assess the adaptation process in this review are well described in protocols and manuals ${ }^{(7)}$ and have been used in conducting systematic reviews of measuring instruments in different contexts, such as assessment of pain ${ }^{(10)}$ and shoulder dysfunction ${ }^{(27)}$.
The use of a methodology for the adaptation process can support the achievement of structural, linguistic and cultural equivalence of health-related instruments. The development of equivalent versions of the same questionnaire decreases the likelihood of the creation of a large number of new instruments in the literature, and facilitates the comparison of information between studies in different countries and cultures.

However, regardless of the selected methodology for the cultural adaptation of an instrument, the articles that deal with this subject should provide more detailed information about the adaptation process adopted and the steps performed; so, researchers will have more elements to evaluate the process and the evidence of the suitability of the adapted instrument to the target language $\mathrm{e}^{(6-7)}$.

Regarding the measurement properties of the instruments, it was observed that these varied among the studies identified in this review. Internal consistency was the property most tested and the majority of the studies presented Cronbach's alpha values above 0.70 , which, according to the literature ${ }^{(12)}$, shows good internal consistency.

The stability was evaluated in 11 studies: five used Kappa index, three ICC, and the other three, correlation coefficients of Pearson or Spearman. According to international recommendations for instrument validation, stability, called by some researchers as reproducibility, and agreement by others, can be assessed over time(test-retest), by different people on the same occasion(inter-observers) or by the same person on different occasions (intraobserver).

The ICC is a statistical test for analysis of stability, and is indicated when the instrument presents quantitative variables ${ }^{(12)}$. This coefficient is adequate to measure the homogeneity of two or more measures, is calculated using a variance ratio, and is interpreted as the proportion of total variability attributed to the measured object ${ }^{(28)}$. For ordinal measures, the Kappa
Measuring instruments in cardiology adapted into Portuguese language of Brazil: a systematic review Cornélio ME, Alexandre NMC, São-João TM 
index of agreement is employed, which is a measure of intra-and inter-observer agreement that measures the degree of agreement between respondents and generally ranges from zero to one (although negative numbers are possible). Values approaching one indicate better reliability; values near or less than zero suggest that the agreement is attributable to chance ${ }^{(29)}$.

The construct and criterion validity were evaluated in most studies, although in different ways and using different statistical tests. For construct validity, exploratory factor analysis was used in most of the articles examined. Factor analysis is a statistical technique used to demonstrate the pattern of responses of a number of items that cannot be explained either by a lower number of underlying factors, or is indicated to assess the dimensionality of the construct of the instrument ${ }^{(30)}$. Construct validity can be further accomplished through the comparison of scores between known groups to differentiate the relevant variables ${ }^{(11)}$.

Criterion validity refers to the extent to which a measurement relates to a gold standard, which is generally a measure of the target construct that is widely accepted in the literature as a measure of the criterion ${ }^{(11)}$. In this review, only the AQUAREL validation ${ }^{(25)}$ showed that criterion validity was properly performed. In the context of self-report measures of health status, such as the evaluation of

\section{REFERENCES}

1. World Health Organization (WHO). Global atlas on cardiovascular disease prevention and control. Geneva; 2011.

2. Roger VL, Go AS, Lloyd-Jones DM, Benjamin EJ, Berry JD, Borden WB, et al. Executive summary: heart disease and stroke statistics-2012 update: a report from the American Heart Association. Circulation. 2012;125(1):188-97.

3. Brasil. Ministério da Saúde. DATASUS. Indicadores e dados básicos: Brasil 2010 [Internet]. Brasília; 2012 [citado 2013 abr. 10]. Disponível em: http://tabnet.datasus.gov.br/cgi/ tabcgi.exe?idb2010/c08.def

4. Gallani MCG, Cornélio ME, Agondi RF, Rodrigues RCM. Estrutura conceitual para pesquisa e prática clínica na mudança de comportamentos em saúde cardiovascular. Rev Latino Am Enferm. 2013;21(n.spec):207-15.

5. Gjersing L, Caplehorn JRM, Clausen T. Cross-cultural adaptation of research instruments: language, setting, time and statistical considerations. BMC Med Res Methodol. 2010;10:13

6. Guillemin F, Bombardier C, Beaton D. Cross cultural adaptation of health quality of life measures: literature review and proposed guidelines. J Clin Epidemiol. 1993;46(12):1417-32. quality of life, criterion validity is rarely used, since there is still an available gold standard measure ${ }^{(11)}$.

Data from this review provided an overview of the availability of measuring tools developed in the context of cardiology which were adapted into Portuguese language of Brazil, making it possible to choose the best questionnaire for the study of a particular cardiac pathology geared to a specific population.

\section{CONCLUSION}

This systematic review of questionnaires developed in the context of cardiology which were adapted into Portuguese language of Brazil showed that, among the studies identified, most assessed quality of life and health knowledge/learning processes. Most accomplished partially or completely the international criteria of the cultural adaptation process for instruments, having presented properties for satisfactory measures.

Hopefully, the results of this study make available to the scientific community a thorough evaluation of the questionnaires adapted into Portuguese language of Brazil to study factors related to cardiology, in order to help researchers and health professionals in the selection of instruments for this field of research.
7. Beaton D, Bombardier C, Guillemin F, Ferraz MB. Recommendations for the Cross-Cultural Adaptation of the DASH \& QuickDASH Outcome Measures. Toronto: Institute for Work \& Health; 2007.

8. De-La-Torre-Ugarte-Guanilo MC, Takahashi RF, Bertolozzi MR. Systematic review: general notions. Rev Esc Enferm USP [Internet]. 2011 [cite 2013 Apr 10];45(5):1260-66. Available from: http://www.scielo.br/pdf/reeusp/v45n5/en_v45n5a33.pdf

9. Moher D, Liberati A, Tetzlaff J, Altman DG; PRISMA Group. Preferred reporting items for systematic reviews and meta-analyses: the PRISMA statement. J Clin Epidemiol. 2009;62(10):1006-12.

10. Costa LCM, Maher CG, McAuley JH, Costa LO. Systematic review of cross-cultural adaptations of McGill Pain Questionnaire reveals a paucity of clinimetric testing. J Clin Epidemiol. 2009;62(9):934-43.

11. Mokkink LB, Terwee CB, Patrick DL, Alonso J, Stratford PW, $\mathrm{Knol} \mathrm{DL}$, et al. The COSMIN study reached international consensus on taxonomy, terminology, and definitions of measurement properties for health-related patient-reported outcomes. J Clin Epidemiol. 2010;63(7):737-45. 
12. Terwee $C B$, Bot SDM, de Boer MR, van der Windt DAWM, $\mathrm{Knol} \mathrm{DL}$, Dekker J, et al. Quality criteria were proposed for measurement properties of health status questionnaires. J Clin Epidemiol. 2007;60(1):34-42.

13. Pelegrino FM, Dantas RA, Corbi IS, Carvalho ARS, Schmidt A, Pazin Filho A. Cross-cultural adaptation and psychometric properties of the Brazilian-Portuguese version of the Duke Anticoagulation Satisfaction Scale. J Clin Nurs. 2012;21(1718):2509-17.

14. Domingues GBL, Gallani MC, Gobatto CA, Miura CTP, Rodrigues RCM, Myers J. Adaptação cultural de instrumento para avaliação da capacidade física em cardiopatas. Rev Saúde Pública. 2011;45(2):276-85.

15. Miura CTP, Gallani MCBJ, Domingues GBL, Rodrigues RCM, Stoller JK. Cultural Adaptation and Reliability Analysis of the Modified Dyspnea Index for the Brazilian Culture. Rev Latino Am Enferm. 2010;18(5):1020-30.

16. Galdeano LE, Rossi LA, Dantas RAS, Rodrigues MA, Furuya RK. Adaptação e validação do Cardiac Patients Learnings Needs Inventory para pacientes brasileiros. Acta Paul Enferm. 2012;25(1):116-21.

17. Feijó MK, Ávila CW, Souza EN, Jaarsma T, Rabelo ER. Crosscultural adaptation and validation of the European Heart Failure Self-care Behavior Scale for Brazilian Portuguese. Rev Latino Am Enferm. 2012;20(5):988-96.

18. Klein C, Linch GFC, Souza EN, Mantovani VM, Goldmeier S, Rabelo ER. Adaptação transcultural e validação de um questionário de conhecimento sobre insuficiência cardíaca para enfermeiros. Rev Gaúcha Enferm. 2012;33(1):19-25.

19. d'Almeida KSM, Souza GC, Rabelo ER. Adaptação transcultural para o Brasil do Dietary Sodium Restriction Questionnaire (Questionário de Restrição de Sódio na Dieta) (DSRQ). Arq Bras Cardiol. 2012;98(1):70-5.

20. Gusmão JL, Pierin AMG. Bulpitt and Fletcher's specific Questionnaire for Quality of Life assessment of hypertensive patients. Rev Esc Enferm USP [Internet]. 2009 [cited 2013 Apr 10];43(n.spe):1034-43. Available from: http://www.scielo. $\mathrm{br} / \mathrm{pdf} /$ reeusp/v43nspe/en_a07v43ns.pdf
21. Rabelo ER, Mantovani VM, Aliti GB, Domingues FB. Cross-cultural adaptation and validation of a Disease Knowledge and Self-Care Questionnaire for a Brazilian sample of heart failure patients. Rev Latino Am Enferm. 2011;19(2):277084.

22. Carvalho VO, Guimarães GV, Carrara D, Bacal F, Bocchi EA. Validação da versão em português do Minnesota Living with Heart Failure Questionnaire. Arq Bras Cardiol. 2009;93(1):3944.

23. Schulz RB, Rossignoli P, Correr CJ, Fernández-Llimós F, Toni PM. Validação do mini-questionário de qualidade de vida em hipertensão arterial (MINICHAL) para o português (Brasil). Arq Bras Cardiol. 2008;90(2):139-44.

24. Ghisi GLM, Leite CM, Durieux A, Schenkel IC, Assumpção MS, Barros MM, et al. Validação para o português do Maugerl CaRdiac preventiOn-Questionnaire (MICRO-Q). Arq Bras Cardiol. 2010;94(3):394-400.

25. Oliveira BG, Melendez JGV, Ciconelli RM, Rincón LG, Torres AAS, Sousa LAP, et al. Versão em português, adaptação transcultural e validação de questionário para avaliação da qualidade de vida para pacientes portadores de marcapasso: AQUAREL. Arq Bras Cardiol. 2006;87(2):75-83.

26. Ghisi GLM, Santos RZ, Schveitzer V, Barros AL, Recchia TL, Oh $P$, et al. Desenvolvimento e validação da versão em português da Escala de Barreiras para Reabilitação Cardíaca. Arq Bras Cardiol. 2012;98(4):344-52.

27. Puga VOO, Lopes AD, Costa LOP. Avaliação das adaptações transculturais e propriedades de medida de questionários relacionados às disfunções do ombro em língua portuguesa: uma revisão sistemática. Rev Bras Fisioter. 2012;16(2):85-93.

28. Shrout PE, Fleiss JL. Intraclass correlations: uses in assessing rater reliability. Psychol Bull. 1979;86(2):420-8.

29. Landis JR, Koch GG. The measurement of observer agreement for categorical data. Biometrics. 1977;33(1):159-74.

30. De Vet HC, Adèr HJ, Terwee CB, Pouwer F. Are factor analytical techniques used appropriately in the validation of health status questionnaires? A systematic review on the quality of factor analysis of the SF-36. Qual Life Res. 2005;14(5):1203-18.

\section{Acknowledgements}

To the São Paulo Research Foundation - FAPESP, for financial support (process number: 2012/15044-0).

Correspondence address to: Marilia Estevam Cornélio Cidade Universitária "Zeferino Vaz" Rua Tessália Vieira de Camargo, 126 CEP 13083-887 - Campinas, SP, Brazil 